NBER WORKING PAPER SERIES

A SIMPLE MODEL OF SUBPRIME BORROWERS AND CREDIT GROWTH

\author{
Alejandro Justiniano \\ Giorgio E. Primiceri \\ Andrea Tambalotti \\ Working Paper 21942 \\ http://www.nber.org/papers/w21942
NATIONAL BUREAU OF ECONOMIC RESEARCH
1050 Massachusetts Avenue
Cambridge, MA 02138
January 2016

We thank Aaron Kirkman for superb research assistance, Simon Gilchrist for useful comments, and Atif Mian and Amir Sufi for kindly sharing their geocodes for the empirical analysis. The views expressed in this paper are those of the authors and do not necessarily represent those of the Federal Reserve Banks of Chicago or New York, or the Federal Reserve System, or the National Bureau of Economic Research. Giorgio Primiceri is a consultant for the Federal Reserve Bank of Chicago and a research visitor at the European Central Bank.

NBER working papers are circulated for discussion and comment purposes. They have not been peerreviewed or been subject to the review by the NBER Board of Directors that accompanies official NBER publications.

(C) 2016 by Alejandro Justiniano, Giorgio E. Primiceri, and Andrea Tambalotti. All rights reserved. Short sections of text, not to exceed two paragraphs, may be quoted without explicit permission provided that full credit, including $(\mathcal{C}$ notice, is given to the source. 
A Simple Model of Subprime Borrowers and Credit Growth

Alejandro Justiniano, Giorgio E. Primiceri, and Andrea Tambalotti

NBER Working Paper No. 21942

January 2016

JEL No. E21,E44,G21

\begin{abstract}
$\underline{\text { ABSTRACT }}$
The surge in credit and house prices that preceded the Great Recession was particularly pronounced in ZIP codes with a higher fraction of subprime borrowers (Mian and Sufi, 2009). We present a simple model with prime and subprime borrowers distributed across geographic locations, which can reproduce this stylized fact as a result of an expansion in the supply of credit. Due to their low income, subprime households are constrained in their ability to meet interest payments and hence sustain debt. As a result, when the supply of credit increases and interest rates fall, they take on disproportionately more debt than their prime counterparts, who are not subject to that constraint.
\end{abstract}

Alejandro Justiniano

Economic Research Department

Federal Reserve Bank of Chicago

230 S. LaSalle Street

Chicago, IL 60604

ajustiniano@frbchi.org

Giorgio E. Primiceri

Department of Economics

Northwestern University

318 Andersen Hall

2001 Sheridan Road

Evanston, IL 60208-2600

and NBER

g-primiceri@ northwestern.edu
Andrea Tambalotti

Federal Reserve Bank of New York

Research and Statistics Group

33 Liberty Street, 3rd Floor

New York, NY 10045

a.tambalotti@gmail.com 


\title{
A SIMPLE MODEL OF SUBPRIME BORROWERS AND CREDIT GROWTH
}

\author{
ALEJANDRO JUSTINIANO, GIORGIO E. PRIMICERI, AND ANDREA TAMBALOTTI
}

Abstract. The surge in credit and house prices that preceded the Great Recession was particularly pronounced in ZIP codes with a higher fraction of subprime borrowers (Mian and Sufi, 2009). We present a simple model with prime and subprime borrowers distributed across geographic locations, which can reproduce this stylized fact as a result of an expansion in the supply of credit. Due to their low income, subprime households are constrained in their ability to meet interest payments and hence sustain debt. As a result, when the supply of credit increases and interest rates fall, they take on disproportionately more debt than their prime counterparts, who are not subject to that constraint.

\section{INTRODUCTION}

During the boom that preceded the Great Recession, aggregate mortgage debt and house prices surged in tandem across the United States, while interest rates fell. This sharp increase in household borrowing, and in the house values that collateralized it, was also characterized by a well-defined geographic pattern. As first documented by Mian and Sufi (2009), both credit and house prices rose disproportionately in ZIP codes with a higher percentage of "subprime" borrowers.

Figure 1.1 reproduces these stylized facts using micro data from the FRBNY Consumer Credit Panel (CCP) and CoreLogic for over seven thousand ZIP codes, focusing on the period between 2000 and 2006. The relationship between cumulative credit growth and the share of subprime borrowers is illustrated in the left panel, where the slope of the regression line is 0.3 . This coefficient implies that mortgage debt over this period grew by 30 percentage points more in a hypothetical ZIP code inhabited only by subprime borrowers, compared to one inhabited only by prime borrowers. Similarly, the right panel of figure

Date: January 2016.

We thank Aaron Kirkman for superb research assistance, Simon Gilchrist for useful comments, and Atif Mian and Amir Sufi for kindly sharing their geocodes for the empirical analysis. The views expressed in this paper are those of the authors and do not necessarily represent those of the Federal Reserve Banks of Chicago, New York or the Federal Reserve System. 

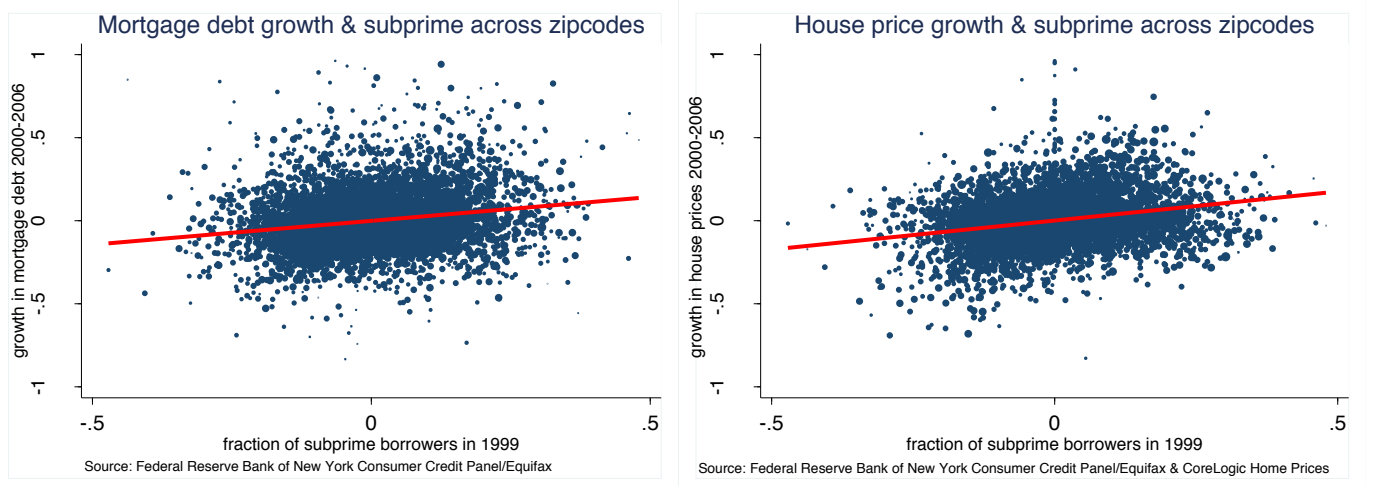

FIGURE 1.1. Cumulative growth of mortgage debt and house prices between 2000 and 2006 plotted against the share of subprime borrowers, defined as those with an Equifax Risk Score under 660 in 1999. The unit of observation is a ZIP code and variables are in deviation from county fixed effects and ZIP code level controls. For further details on the regression line, see Table 1.

1.1 shows that the slope for the cumulative growth in house prices in the corresponding regression is $0.35 .^{1}$

The fact that aggregate debt rose and interest rates declined during this period points to an expansion in the supply of credit as the ultimate driver of the boom. In Justiniano et al. (2015b), we formalize this intuition through a simple general equilibrium model, in which the expansion in credit supply is brought about by a relaxation of lending constraints, or equivalently, of leverage restrictions on financial intermediaries. A progressive reduction in these barriers to lending, which captures the explosion of securitization and of market-based financial intermediation starting in the late 1990s, produces a credit boom in the model that is consistent with four key aggregate stylized facts about the U.S. economy in the early 2000s: the surge in house prices and in household debt, the stability of debt relative to home values, and the fall in mortgage rates.

The contribution of this paper is to confront this same mechanism with the cross-sectional evidence presented above. To do so, we extend the representative borrower model of Justiniano et al. (2015b) to include both prime and subprime borrowers, which we assume are heterogeneously distributed across ZIP codes. We then subject a calibrated version of this economy to a progressive relaxation of lending constraints that increases the supply of credit, reducing interest rates from 5 to 2.5 percent, roughly as observed in the data between 2000 and 2006 .

\footnotetext{
${ }^{1}$ Further details on the data underlying these figures are in the Appendix.
} 
The main result of this experiment is that, in response to the expansion in credit supply, the model closely reproduces the distribution of increases in mortgage debt and house prices across ZIP codes described above. In particular, ZIP codes with a higher fraction of subprime borrowers experience higher increases in both debt and house prices, with a slope of approximately 0.25 , remarkably close to the empirical slopes of 0.3 and 0.35 for debt and house prices depicted in figure 1.1. ${ }^{2}$

The intuition for the more pronounced increase in debt among subprime borrowers is fairly straightforward, and arguably realistic. Subprime households have low income, and hence a limited capacity to afford interest payments. This limit, in turn, constrains their ability to borrow and hence the value of the house that they can purchase. In contrast, prime households are richer and only subject to a collateral constraint that limits their borrowing to a fraction of the value of their real estate.

As a result of this asymmetry, the two types of households respond differently to the fall in interest rates and the rise in house prices that are triggered by the expansion in credit supply. Prime households' collateral constraint slackens as a function of the equilibrium increase in the value of real estate, driving the increase in their debt. Instead, subprime households get a direct boost to their ability to borrow from the fall in the interest rate, which makes bigger mortgages affordable for them, driving up their housing demand. In equilibrium, this latter effect is always larger, leading to more debt accumulation by subprime borrowers, and to larger house price increases in areas in which those borrowers are more concentrated.

In terms of the empirical evidence that motivates the analysis, our paper is related to the large literature on the evolution of debt, house prices and other macroeconomic variables across the United States before and after the recent financial crisis, which was pioneered by Mian and Sufi (2009) and Mian and Sufi (2011) (e.g. Di Maggio and Kermani, 2014; Favara and Imbs, 2012; Ferreira and Gyourko, 2015; Foote et al., 2012; Mian et al., 2013; Mian and Sufi, 2014). Recently, the implications of their ZIP code level evidence for the trajectories of individual debt across the credit score spectrum have been called into question by Adelino et al. (2015a and 2015b) and Albanesi et al. (2016), but re-asserted in Mian and Sufi (2015a and 2015b). Since we confront our model directly with evidence at the ZIP code,

\footnotetext{
${ }^{2}$ In the model, this slope is the same for debt and house prices, since borrowing is limited to a constant fraction of the value of real estate, whose supply is constant. As a result, debt and house prices move one to one in equilibrium.
} 
rather than at the individual level, our conclusions should be robust to the resolution of this debate.

In terms of theory, this paper is related to a fast growing literature that has developed general equilibrium frameworks to study the causes and consequences of the boom and bust in credit and house prices over the last decade (e.g. Favilukis et al., 2013, Kermani, 2012, Justiniano et al., 2014, 2015a and 2015b, Kehoe et al., 2014, Berger et al., 2015, Greenwald, 2015, Kaplan et al., 2016). Among these papers, perhaps the closest in spirit to ours is Midrigan and Philippon (2011), who also propose a model with an explicit geographic structure. The most notable difference is that they emphasize the role of housing in facilitating transactions and hence non-durable consumption. On the contrary, we focus on how the relaxation of lending constraints lowers interest rates and boosts both house prices and mortgage debt.

\section{A Simple Model with Subprime Borrowers}

This section presents a simple macroeconomic framework to address the cross-sectional facts discussed in the introduction. The model features impatient borrowers and more patient lenders. Lenders are the same as in Justiniano, Primiceri, and Tambalotti (2015b, henceforth JPT), except that for simplicity we assume here that they do not own houses. Lenders have a discount factor $\beta_{l}$ and face a lending limit, denoted by $\bar{L}$. This restriction on the ability of savers to extend credit captures a variety of implicit and explicit regulatory, institutional and technological constraints that hamper the free flow of funds towards mortgage borrowers, as discussed at length in JPT.

2.1. Prime and subprime borrowers. To address the cross-sectional evidence presented in the introduction, we introduce a distinction between two sets of borrowers, prime $(p)$ and subprime $(s)$. Both have a discount factor $\beta<\beta_{l}$, but the latter are poorer. In the data, subprime borrowers are usually identified by their low credit score. For example, Mian and Sufi (2009) set this threshold at a FICO score of 660. Credit scores, which are primarily designed to capture risk of default, depend on a person's credit history, and hence are correlated with the level and volatility of individual income. Here, we base the distinction between prime and subprime borrowers on their level of income alone, both for simplicity, and because this characteristic correlates strongly with the credit score (e.g. Mayer and Pence, 2009, Mian and Sufi, 2009). 
Borrowers are distributed across geographic areas, say ZIP codes, which are indexed by the fraction $\alpha$ of subprime households that live there. Households in these locations borrow from a representative national (or international) lender at interest rate $R_{t}$, using houses as collateral. They can trade houses within a ZIP code, but not across them, and they cannot migrate. In the model, some equilibrium prices and allocations depend on $\alpha$, but we explicitly introduce this dependence only at a later stage, to streamline the notation.

In each location, representative borrower $j=\{p, s\}$ maximizes utility

$$
E_{0} \sum_{t=0}^{\infty} \beta^{t}\left[c_{j, t}+v\left(h_{j, t}\right)\right],
$$

where $c_{j, t}$ denotes consumption of non-durable goods, and $v\left(h_{j, t}\right)$ is the utility of the service flow derived from a stock of houses $h_{j, t}$ owned at the beginning of the period. Households purchase new houses from local house producers, who receive an endowment of houses that is just enough to cover depreciation in that area, leaving the overall supply of houses fixed at $\bar{h}$. House producers sell this endowment to households and simply consume the proceedings.

Assuming that utility is linear in non-durable consumption, as in JPT, helps to obtain clean analytical solutions, without compromising the model's basic mechanisms. However, here we accompany this simplifying assumption with the explicit consideration that consumption cannot fall below a subsistence level $\underline{c}$, i.e.

$$
c_{j, t} \geq \underline{c}
$$

If we ignored this constraint, which is usually enforced at zero by suitable Inada conditions, consumption could become very low or negative, depending on the level of income. As shown below, this lower bound on consumption effectively imposes a maximum coverage ratio - a limit on the amount of debt-service payments that low-income borrowers can afford at a given interest rate.

Utility maximization is subject to the flow budget constraint

$$
c_{j, t}+p_{t}\left[h_{j, t+1}-(1-\delta) h_{j, t}\right]+R_{t-1} D_{j, t-1} \leq y_{j, t}+D_{j, t}
$$

where $\delta$ is the depreciation rate of houses, $p_{t}$ is their price in terms of the consumption good, and $D_{j, t}$ is the amount of one-period debt accumulated by the end of period $t$, and 
carried into period $t+1$, with gross interest rate $R_{t} . y_{j, t}$ is an exogenous endowment of consumption goods, which is lower for subprime borrowers, so that $y_{s, t}<y_{p, t}$.

Finally, borrowers' decisions are subject to a collateral constraint a la Kiyotaki and Moore (1997), which limits debt to a fraction $\theta$ of the value of the housing stock they own,

$$
D_{j, t} \leq \theta p_{t} h_{j, t+1}
$$

where $\theta$ is the maximum allowed loan-to-value ratio. This ratio could in principle be different for prime and subprime borrowers, but we will abstract from this source of heterogeneity here.

2.2. Steady-state equilibria. The steady state of the model presented in the previous section depends on the parameter configuration, which determines the constraints that bind in equilibrium. For instance, when the income of both households is high enough with respect to the subsistence point $\underline{c}$, the minimum consumption constraint does not bind. In this case, the model's equilibria are the same as those studied in JPT, with no distinction between prime and subprime borrowers. On the contrary, prime and subprime borrowers behave differently when the consumption constraint binds for one of the two groups. This is the interesting case developed in what follows. In particular, we will assume that the income of subprime borrowers, $y_{s}$, is low enough to push their consumption against the subsistence point, while prime borrowers are always away from this constraint.

Another important parameter in determining the model's steady state is $\bar{L}$, which determines the tightness of lending constraints. If $\bar{L}$ is very low, making lending constraints tight, the supply of credit is not sufficient to satisfy the demand. On the contrary, if $\bar{L}$ is very high, households can borrow up to their collateral limit, making lending constraints irrelevant. As shown in JPT, the most interesting equilibria are those corresponding to intermediate values of $\bar{L}$, where both lending and borrowing constraints bind.

In what follows, we characterize the model's steady state analytically in the region in which a) the income of subprime borrowers, $y_{s}$, is low enough to push their consumption against the subsistence point, b) prime borrowers are always away from this constraint, and c) both lending and borrowing constraints bind.

First, if the borrowing constraint is binding for any agent, it must be binding for both subprime and prime borrowers, since their consumption Euler equations are identical due 
to the assumption of linear utility in consumption. Therefore we have

$$
\begin{gathered}
D_{p}=\theta p(\alpha) h_{p}(\alpha) \\
D_{s}=\theta p(\alpha) h_{s}(\alpha),
\end{gathered}
$$

where the dependence of certain variables on $\alpha$ in equilibrium is now made explicit. Moreover, the budget constraint of the subprime agents, together with $c_{s}=\underline{c}$, implies

$$
D_{s}=\frac{y_{s}-\underline{c}-\delta p(\alpha) h_{s}(\alpha)}{R-1}
$$

Although this equation is derived under stylized assumptions, it captures quite literally the idea that poor, subprime households are likely to be in a "corner." Their borrowing is limited by the present discounted value of their disposable income, once they have met the subsistence level of consumption and replaced the depreciated portion of their house. Multiplying both sides by $R-1$ makes clear that (2.4) represents a coverage limit on mortgage obligations, restricting the amount of debt that a borrower can take on as a function of the income at her disposal to service the debt. This restriction is similar to that assumed by Gelain et al. (2013) or Greenwald (2015).

Equation (2.4), together with the binding collateral constraint (2.3), implies the following housing demand equation for subprime households

$$
p(\alpha)=\frac{y_{s}-\underline{c}}{(R-1) \theta+\delta} \cdot \frac{1}{h_{s}(\alpha)}
$$

from which we see that their housing expenditure is limited by their ability to make mortgage payments, and hence to take on leverage.

In contrast, prime households, whose minimum consumption constraint does not bind, price housing according to a fairly standard Euler equation, adjusted for the effect of the binding borrowing constraint. Assuming $v(h)=\phi \ln h$, the steady state pricing equation for prime borrowers is

$$
p(\alpha)=\frac{\beta}{1-\theta \mu-(1-\delta) \beta} \frac{\phi}{h_{p}(\alpha)},
$$

where $\mu$ is the multiplier on the collateral constraint. ${ }^{3}$ With the marginal utility of consumption normalized to one, $\phi / h_{p}$ is the marginal rate of substitution between housing and

\footnotetext{
${ }^{3}$ In equilibrium this multiplier is the same for $p$ and $s$ agents, which is why there is no subscript.
} 
non-durable consumption for prime households. Therefore, their valuation of housing is the present discounted value of this MRS, where the discount is adjusted by a collateral "premium" $\theta \mu$, which depends on the maximum allowed leverage $(\theta)$, and on the tightness of the borrowing constraint $(\mu)$.

Together with housing market clearing in each ZIP code, $\alpha h_{s}(\alpha)+(1-\alpha) h_{p}(\alpha)=\bar{h}$, the two housing demand equations yield

$$
p(\alpha)=\left[\alpha \frac{y_{s}-\underline{c}}{(R-1) \theta+\delta}+(1-\alpha) \frac{\beta \phi}{1-\mu \theta-(1-\delta) \beta}\right] \frac{1}{\bar{h}},
$$

from which we see that house prices are a weighted average of the valuations of prime and subprime households, making them a function of the share of the latter in each ZIP code. ${ }^{4}$ Similarly, total debt in each ZIP code is

$$
D(\alpha)=\alpha D_{s}+(1-\alpha) D_{p}=\theta p(\alpha) \bar{h}
$$

and therefore also depends on the share of subprime households in that area, through its effect on house prices.

Since subprime borrowers spend less in housing than their prime counterparts, housing expenditure, house prices and mortgage debt are lower in areas with a higher share of subprime households. However, a relaxation of credit supply that lowers interest rates directly reduces mortgage payments for subprime households, allowing them to expand their borrowing and house purchases more than prime households. Therefore, home prices and debt will grow more in areas with a higher fraction of subprime borrowers when interest rates fall, despite starting from a lower level. The next section studies this cross-sectional response of the economy to a relaxation of lending constraints in a calibrated version of the model.

\section{An Increase in CRedit Supply}

In this section, we parametrize the model and study quantitatively the response of house prices and household debt to an outward shift in credit supply, due to a slackening of the lending constraint $\bar{L}$. The main result of this experiment is a more pronounced increase in home values and mortgage debt in ZIP codes with a larger share of subprime borrowers, to an extent very similar to that documented in the introduction.

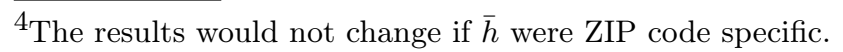


3.1. Parameter values. The quarterly calibration of the model is based on U.S. macro and micro targets. The economy's initial steady state is characterized by tight lending constraints, implying that mortgage rates are equal to $1 / \beta$. Hence, we set $\beta=0.9879$ to match the 5-percent average value of real mortgage rates in the 1990s, as in JPT. When lending constraints no longer bind, following the rise in $\bar{L}$, interest rates switch to being pinned down by the discount factor of the lenders. Therefore, we choose $\beta_{l}=0.9938$ to match the approximate 2.5-percent decline in mortgage rates experienced in the first half of the 2000s.

The depreciation rate of houses $(\delta)$ is set equal to 0.003, based on the NIPA Fixed Asset Tables. The calibration of the loan-to-value ratio $(\theta)$ is based on the 1992, 1995 and 1998 rounds of the Survey of Consumer Finances, a triennial statistical survey of the balance sheet of US families. We identify "borrowers" in these data as those households who own a house and have little liquid financial assets (Kaplan and Violante, 2014). Their average ratio of debt to real estate is 0.43 , which is the value used for $\theta .^{5}$

Finally, the composite parameter $\frac{y_{s}-\underline{c}}{\phi}$ is key for the quantitative properties of the model. If $\frac{y_{s}-\underline{c}}{\phi}$ is large, prime and subprime borrowers are identical, and the model implies the same response of mortgage debt across geographic areas during the housing boom. in contrast, the smaller is $\frac{y_{s}-\underline{c}}{\phi}$, the larger the region of the parameter space in which subprime borrowers are constrained by their income, and hence the stronger their response to a credit supply expansion that reduces interest rates. We calibrate $\frac{y_{s}-\underline{c}}{\phi}$ to match the relative mortgage debt of the average subprime and prime borrowers in the CCP. In this dataset, we identify subprime borrowers as those individuals with a Risk Score less than or equal to 660 in 1999, which is the earliest year available. This criterion classifies 36 percent of borrowers as subprime. ${ }^{6}$ Based on these data, the ratio between mortgage debt of the average subprime and prime borrower in 1999 is 0.74 , which is our target to set $\frac{y_{s}-\underline{c}}{\phi}$.

3.2. The experiment. Given these parameter values, we study the effects of a progressive relaxation of the lending constraint, which moves the economy from a steady state with high mortgage rates, low debt and low house prices circa 2000, to one with low mortgage rates, high debt and high house prices around 2006. As shown in JPT, this experiment captures

\footnotetext{
${ }^{5}$ An alternative, simpler way to identify the borrowers is as those individuals with a mortgage. This alternative definition produces a very similar calibration of $\theta=0.4$.

${ }^{6}$ The Equifax credit score (Risk Score) covers the range 280 to 850 , similar, but not identical to the wellknown FICO score (350-850).
} 


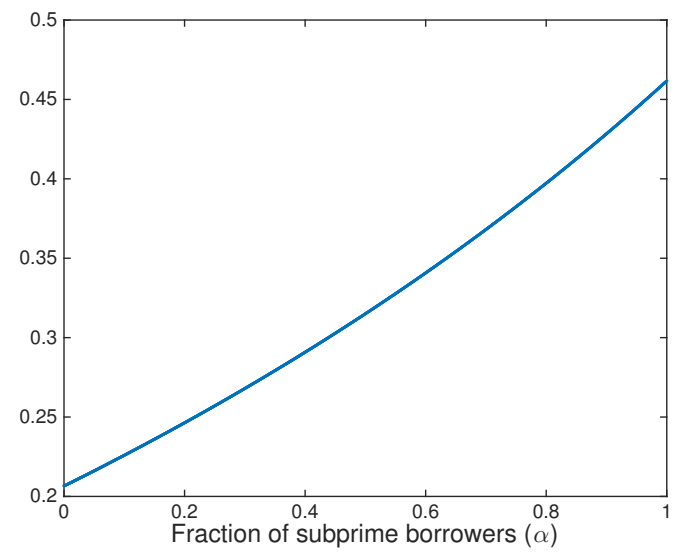

FIgURE 3.1. Model-implied cumulative credit and house price growth as a function of the share of subprime borrowers in a geographic area.

the main aggregate dimensions of the housing boom. The question that we ask in this section is if it can also reproduce the cross-sectional evidence presented in the introduction.

The premise of this exercise is that at the end of the 1990s the U.S. economy was constrained by a limited supply of credit. In this initial steady state, we set $\bar{L}$ so that the lending constraint is binding and the interest rate is equal to $\frac{1}{\beta}$, as in JPT. ${ }^{7}$ We then increase $\bar{L}$ until the economy reaches a new steady state in which the lending constraint is not binding, and, consequently, the interest rate falls to $\frac{1}{\beta_{l}}$. This reduction in the interest rate enhances the ability of both types of borrowers to take on debt, but at different rates.

Figure 3.1 plots the model-implied percentage increase in household debt in a given ZIP code associated with the move from the initial to the final steady state, as a function of the fraction $\alpha$ of subprime borrowers in that ZIP code. The figure shows that mortgage debt, and hence home values, which in the model move together due to the binding collateral constraint, grow more in locations with a higher share of subprime borrowers, as in the data.

Quantitatively, we assess the ability of the model to reproduce the cross-sectional evidence along several dimensions. First, the model implies that the typical subprime and

\footnotetext{
${ }^{7}$ More precisely, if $\bar{L}$ is too low, the supply of credit is not sufficient to satisfy the demand, requiring a rationing rule to split the available funds between the two types of borrowers. To avoid this complication, in the initial steady state we set $\bar{L}$ to the minimum value that does not require the use of a rationing rule. In fact, a reasonable rationing rule would imply that credit is extended to prime borrowers first. In this case, therefore, it would follow quite mechanically that an expansion in credit supply generates a larger increase in debt for the subprime borrowers, thereby strengthening our results.
} 
prime borrowers should experience an increase in debt of approximately 46 and 21 percent, respectively. These values can be read on the vertical axis in figure 3.1 at $\alpha=1$ (the ZIP code in which all borrowers are subprime ) and $\alpha=0$ (the ZIP code in which all borrowers are prime). In the CCP, the percentage increase in real mortgage balances of the average subprime and prime borrowers between 2000 and 2006 is 62 and 39 percent respectively. Therefore, the model is able to generate about two thirds of the observed increase in debt for the two classes of borrowers. In relative terms, however, the model reproduces the data almost exactly. In the initial steady state, the relative debt of subprime to prime borrowers is calibrated to 74 percent. It rises to 90 percent in the final steady state, compared to 87 percent in the data in 2006 .

Second, we compare the slope of the curve in figure 3.1 to those of the regression lines in figure 1.1. Column $\mathrm{A}$ in table 1 reports a coefficient of 0.3 when regressing cumulative mortgage credit growth between 2000 and 2006 on the share of subprime borrowers across ZIP codes. ${ }^{8}$ This slope is virtually identical to that of the curve obtained from the model, which is close to a straight line.

Finally, in the model the percentage increase in credit when moving from one steady state to the other is equal to that in home values. To test this implication, column B in table 1 displays the regression coefficient of ZIP code level house price growth between 2000 and 2006 from CoreLogic on the same share of subprime borrowers as before. The slope of this relationship (0.35) is quite close to the 0.3 estimated for credit growth, suggesting that in the data, as in the model, debt and house prices grew closely together in the cross-section during the boom.

\section{Conclusion}

As documented by Mian and Sufi (2009), house prices and mortgage debt between 2002 and 2005 surged more in ZIP codes with a higher concentration of subprime borrowers. We presented a simple model that is consistent with this empirical evidence, which we also extend to the period between 2000 and 2006, to cover a larger swath of the boom.

\footnotetext{
${ }^{8}$ This slope is very close to that estimated by Mian and Sufi (2009) in similar regressions, for instance in the fifth column of their table V, once we take into account that they only look at the period 2002 to 2005 and that their left-hand-side variable is annualized. Since Mian and Sufi (2009) use the share of subprime borrowers in 1996, this similarity should ameliorate concerns of possible reverse causality due to, say, gentrification dynamics (Guerrieri et al., 2013).
} 


\begin{tabular}{ccc}
\hline & A & B \\
& MorTGAGE DEBT & House PRICE \\
& GROwTH 2000-06 & GROwTH 2000-06 \\
\hline $\begin{array}{c}\text { share of subprime } \\
\text { borrowers in 1999 }\end{array}$ & 0.30 & 0.35 \\
county fixed-effects & $(0.06)$ & $(0.09)$ \\
and ZIP-level controls & yes & yes \\
$\#$ observations & & 7,005 \\
\hline
\end{tabular}

TABLE 1. Coefficient estimates of a regression of mortgage debt and house price growth from 2000 to 2006 on the share of subprime borrowers in 1999. The unit of observation is a ZIP code, and observations are weighted by population in 2000 . ZIP code level controls include the growth rate of employment, annual payroll and number of establishments between 2000 and 2006. Standard errors are clustered at the MSA level. Source: FRBNY CCP/Equifax, CoreLogic and authors' calculations.

The key ingredient of the model is a distinction between two types of borrowers, based on their income level. Due to the presence of a minimum consumption level, poorer borrowers face an upper limit on the mortgage payments they can afford. For this reason, we label them "subprime". In this environment, an expansion in credit supply that lowers mortgage rates enhances all borrowers' ability to acquire additional debt. However, the effect is larger for subprime borrowers, since it directly lowers their mortgage payments, hence slackening the coverage ratio constraint that they are effectively subject to. A calibration using micro data from the CCP and the Survey of Consumer Finances shows that the model is quantitatively consistent with the evidence about the higher growth of debt and house prices in ZIP codes with relatively more subprime borrowers.

\section{ApPendix A. DATA DESCRIPTION}

Our empirical work and model calibration are based on the FRBNY Consumer Credit Panel (CCP), which is a quarterly dataset on household liabilities based on consumer credit data from Equifax. The CCP provides detailed panel data on a 5\% representative sample of all individuals with a credit history in the U.S., from 1999 through the present. Our 
measure of mortgage debt is the variable "All Mortgage Balances," which captures the sum of first, second, third, and higher outstanding mortgage obligations. ${ }^{9}$

For the purpose of sorting borrowers into prime and subprime, the sample is restricted to individuals observed continuously for all quarters between 1999 and 2006, without a missing observation in their credit score. This restriction results in a panel of roughly 7.7 million individuals, for a total of about 246 million individual-quarter observations. Subprime borrowers are defined as those with an average credit score of less than 660 in 1999. They represent 36 percent of the panel. This definition is similar to that adopted by Mian and Sufi (2009), although they identify subprime borrowers using their 1996 credit score. Having classified borrowers, we compute the growth rates of mortgage debt of the average subprime and prime borrower between 2000 and 2006, and transform them in real terms by subtracting realized inflation from the CPI. This is how we obtain the 39 and 62 percent numbers reported in section 3.2.

For the data underlying figure 1.1 and table 1, we work with all primary borrowers in the CCP without a missing credit score and ZIP code for the years 1999, 2000 and 2006. For each ZIP code, we construct the growth rate of mortgage debt between 2000 and 2006 by dividing total mortgage balances by the number of individuals with a positive balance. Data on house prices at the ZIP-code level are from CoreLogic. Data on employment, annual payroll and number of establishments at the ZIP-code level are from the County Business Patterns Census database. Using the geocodes of Mian and Sufi (2009), we match data on house prices and mortgage debt for 7,005 ZIP codes and 301 counties that account for two thirds of all borrowers in 2000 .

\section{REFERENCES}

Adelino, M., A. Schoar, And F. Severino (2015a): "Loan Originations and Defaults in the Mortgage Crisis: Further Evidence," NBER Working Papers 21320, National Bureau of Economic Research, Inc.

_ (2015b): "Loan Originations and Defaults in the Mortgage Crisis: The Role of the Middle Class," NBER Working Papers 20848, National Bureau of Economic Research, Inc.

\footnotetext{
${ }^{9}$ In the CCP, second or third mortgages are sometimes misclassified as home equity debt, and vice versa. For this reason, we also construct an alternative comprehensive mortgage measure that adds to "First Mortgage Balances" all "Home Equity Installment and Revolving Debt." Results with this alternative series are similar to our baseline and available upon request.
} 
Albanesi, S., G. De Giorgi, J. Nosal, and M. Ploenzke (2016): "Credit Growth and the Financial Crisis: A New Narrative," Mimeo, Ohio State University.

Berger, D., V. Guerrieri, G. Lorenzoni, and J. Vavra (2015): "House Prices and Consumer Spending," Mimeo, Northwestern University.

Di Maggio, M. And A. Kermani (2014): "Credit-Induced Boom and Bust," Mimeo, Columbia University.

Favara, G. AND J. Imbs (2012): "Credit Supply and the Price of Housing," Mimeo, Boad of Governors of the Federal Reserve System.

Favilukis, J., S. C. Ludvigson, and S. V. Nieuwerburgh (2013): "The Macroecononomic Effects of Housing Wealth, Housing Finance, and Limited Risk Sharing in General Equilibrium," New York University, mimeo.

Ferreira, F. And J. Gyourko (2015): "A New Look at the U.S. Foreclosure Crisis: Panel Data Evidence of Prime and Subprime Borrowers from 1997 to 2012," NBER Working Papers 21261, National Bureau of Economic Research, Inc.

Foote, C. L., K. S. Gerardi, And P. S. Willen (2012): "Why Did So Many People Make So Many Ex Post Bad Decisions? The Causes of the Foreclosure Crisis," NBER Working Papers 18082, National Bureau of Economic Research, Inc.

Gelain, P., K. J. Lansing, and C. Mendicino (2013): "House Prices, Credit Growth, and Excess Volatility: Implications for Monetary and Macroprudential Policy," International Journal of Central Banking, 9, 219-276.

Greenwald, D. L. (2015): "The Mortgage Credit Channel of Macroeconomic Transmission," Mimeo, New York University.

Guerrieri, V., D. Hartley, and E. Hurst (2013): "Endogenous gentrification and housing price dynamics," Journal of Public Economics, 100, 45-60.

Justiniano, A., G. Primiceri, and A. Tambalotti (2015a): "Household leveraging and deleveraging," Review of Economic Dynamics, 18, 3-20.

Justiniano, A., G. E. Primiceri, And A. Tambalotti (2014): "The Effects of the Saving and Banking Glut on the U.S. Economy," Journal of International Economics, 92, Supplement 1, S52-S67.

_ (2015b): "Credit Supply and the Housing Boom," Working Paper 20874, National Bureau of Economic Research.

Kaplan, G., K. Mitman, and G. Violante (2016): "Consumption and House Prices in the Great Recession: Model meets Evidence," Mimeo, Princeton University. 
Kaplan, G. And G. Violante (2014): "A Model of the Consumption Response to Fiscal Stimulus Payments," Econometrica.

Kehoe, P., V. Midrigan, and E. Pastorino (2014): "Debt Constraints and Employment," Mimeo, New York University.

Kermani, A. (2012): "Cheap Credit, Collateral and the Boom-Bust Cycle," Mimeo, University of California.

Kiyotaki, N. And J. Moore (1997): "Credit Cycles," Journal of Political Economy, 105, 211-48.

Mayer, C. J. And K. Pence (2009): "Subprime Mortgages: What, Where, and to Whom?" in Housing Markets and the Economy: Risk, Regulation, and Policy, ed. by E. L. Glaeser and J. M. Quigley, Lincoln Institute of Land Policy, Cambridge, MA.

Mian, A., K. Rao, And A. Sufi (2013): "Household Balance Sheets, Consumption, and the Economic Slump," Quarterly Journal of Economics, 128(4), 1687-1726.

Mian, A. And A. Sufi (2009): "The Consequences of Mortgage Credit Expansion: Evidence from the U.S. Mortgage Default Crisis," The Quarterly Journal of Economics, 124, 1449-1496.

_ (2011): "House Prices, Home Equity-Based Borrowing, and the US Household Leverage Crisis," American Economic Review, 101, 2132-56.

_ (2014): "What Explains the 2007-2009 Drop in Employment?" Mimeo, Princeton University. (2015a): "Household Debt and Defaults from 2000 to 2010: Facts from Credit Bureau Data," Princeton University, mimeo.

Mian, A. R. AND A. Sufi (2015b): "Fraudulent Income Overstatement on Mortgage Applications during the Credit Expansion of 2002 to 2005," NBER Working Papers 20947, National Bureau of Economic Research, Inc.

Midrigan, V. And T. Philippon (2011): "Household Leverage and the Recession," New York University, mimeo.

Federal Reserve Bank of Chicago

E-mail address: ajustiniano@frbchi.org

Northwestern University, CEPR, AND NBER

E-mail address: g-primiceri@northwestern.edu

Federal Reserve Bank of New York

E-mail address: a.tambalotti@gmail.com 